The feas of some policyplanters is-to borrow the description of U.S. Neus and World Report -that Chancellor Brmdt "is the man who is, perlaps monowingly or otherwise, on the verge of handing over the continent to the Reds," who is "selling out the Western Alliunce in his anxiety to strike a bargain with the Sovict Untom and other Furopean Commumist States."

Well, those are large fears and the substantive issues are great indeed. But cim one believe that Willy Brandt is much less sophisticated about Soviet intentions and practices than his Anericin friends? Liftle in Brandt's life or ceareer substantiates such a belief. He has been long known as a pro-Wostem, anti-fascist, anti-Commumist political lestler. who has served honorably as the masor of W(est Berlin-no sinecure-and as Bonn's Forcigi Minister. Furthermore, he lias said that lais Ostpolitik, which is stirring up so much controversi, is based solidly upon lis Westpolitik. Jle acknowledges, indeed insists, that West Germaix must mitintain clese ties with the U.S., that 7.5 . Iorces in Eurepo are necessary until the situition resolves itșelf nore favorably.

But, it is argued, even if we grant Brandt's sincerity ant intelligence, mat he not yet be wong? Is it not possible that in his understandille need to Gorge policies for West Gormany, to assme a position of political leadership in Europer, that he minimizes discomts or simply fails to gratsp the larger strategies which must he the concerm of the Uinited States to which his own plexis rin? counter?

Yis, all this is possible. Such possibilitics comstitute much of the stuff of international diplomiace. But there are chamels for the relatively orderly disposition of such prollems as the arise. We have the State Department and a President, for cxample, who are aware of and responsible for forging the necessary decisions. If Messrs. Ball, Ache'son and others wish to convey their informed concerns to those in charge, they have the meanis to do so. What they are doing, however, is to use both their kirowledge of Cemm affars, their reputations within Gemany, and political clout at home to campaign publicly against a $W_{\text {est }}$ German policy which they fail to approve.

Is such behavion rosponsilyle? The is sues thenselves aside, there is little donbt that were people witls shaply different wews to engage in analogous activities thev would receive a definite, no:nonsense, swift reply to that question. The quirestion is worth pursuing.

J.F:

\section{THE TREACHEROUS TRAP}

Some years ago in a document issuing from Vatican Council II, the fathers of the Catholic Church described the arms race as a "treacherons trap." Of all the descriptions lavished upon the arms race, that still stands as the most duralble, most applicable today as yesterday. The ongoing SALT talks stand a chance of becoming it part of the treachery, a part of the trap.

Established to explore the avonues that might lead to strategic arms limitation, the SALT talks, it is reportcd, may lead to another step in the race. If so, it would be irony compounded, with concomitant rish. It was Reinhold Niebuhr who dcscribed a situation as ironic "if strength becomes weakness because of the vanity to which strength may prompt the mighty man or uation; if security is transmitted into insecurity because too much reliance is placed upon it; if wisdom becomes folly because it does not know its own limits."

The quotation is apt here because the U.S. and the USSR move into the arms race, and into tlic arms talks with real strength, the desire for security ind with a measure of wisdom. They are not stupicl, weak nor ill-informed men who have the responsibility for the decisions that may emerge from the SALT talks. Quite the reverse. But if, as it is reported, they are unable to agree on the limitation of the A.B.M. systems, more potent offensive systems will follow. Fortunately, it is also reported that the USSR is interested in such limitations. This does not mean that the U.S. must agree immediately and without examination to it mutual pact to limit the development of the A.B.M. systems. But there is real reason to take some risk here. There is, in fact, risk in either direction, but one leads further into the treacherons trap, the other holds out hope that we can back some distance away from it.

We amounce with regret the departure of Dr. Emest. Lefiver from the masthead of wonldiew. After one year he has, he informs us, found the pressure of his other work too great to allow him to contime as a contributing editor. To do publicly what we have done privately, we would like to thank him for the singular contribution he has made to worldview by the very clear expression of definite views, and we invite him to send letters and articles as his time and interest allow. 